\title{
Singing as a therapeutic agent in Pentecostal worship
}

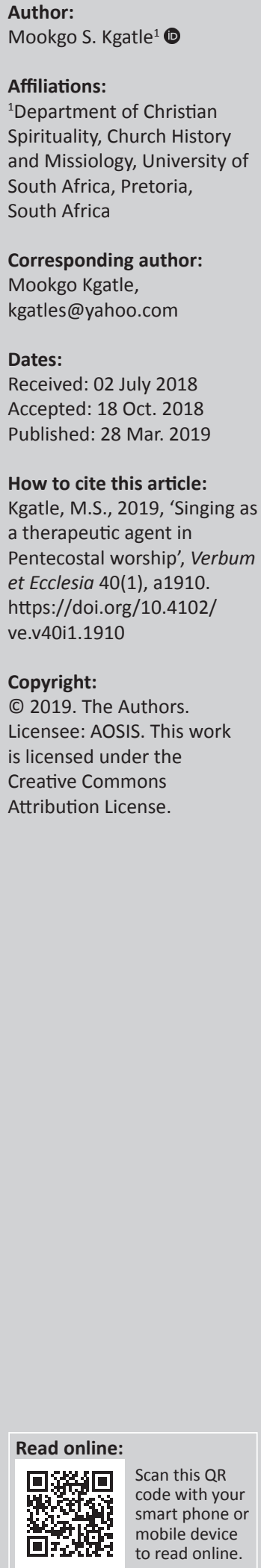

Singing has always been part of worship in a Pentecostal spiritual service. However, the role of singing in Pentecostal worship as a therapeutic agent has been under-researched. In order to bridge this research gap, this article is an interdisciplinary study of singing and Pentecostal worship. It seeks to demonstrate that the act of singing is a therapeutic agent in Pentecostal worship. The article will explore singing as a biblical concept to establish its theology. The purpose is to demonstrate that singing is not only part of the liturgy in a Pentecostal worship service but also acts as a therapeutic agent for all sorts of ailments, including spiritual, physical, emotional and psychological ailments.

Intradisciplinary and/or interdisciplinary implications: The importance of this article is twofold; firstly, the article demonstrates that singing plays a pivotal role in Pentecostal worship as much as it did in the Bible. Secondly, the article illustrates that singing is more than a liturgical exercise; it acts as a therapeutic agent in Pentecostal worship.

Keywords: Pentecostalism; worship; therapy; singing; music.

\section{Introduction}

Singing was part of African culture before it was part of Pentecostal worship. In the words of Lebaka (2014:1), 'singing is such a strong ethnic symbol that it is virtually indistinguishable from the culture itself'. Africans sing to demonstrate that they are happy. The whole concept of parties and other forms of celebrations, for example birthday parties, graduations, house-warmings and baby showers, are all platforms to gather friends and family in order to sing. At such parties, some even hire a deejay to play music. Equally, Africans sing during sad times, such as mourning the loss of loved ones during funerals. During night vigils, they sing the whole night until the early morning of the following day. In a way singing helps them to forget their sorrows. They will sing ga Modimo a le teng gayo mathata, which means 'when God is present, there are no problems'.

Singing has always been part of political events. Politicians gather and sing slogans as a way of charming their supporters or keeping the event going. Former president of South Africa Jacob Zuma is known for his singing more than his politics. He moved from singing Umshini wami, awuleth' umshini wami, which means 'bring back my gun', to singing inde lendlela esiyihambayo, illustrating that the walk to freedom is a long one. At times the singing of struggle songs brought politicians into trouble, like the Dubula ibhunu song, which means 'kill the Boer', by Julius Malema. I am quoting these examples here to illustrate that singing has always been part of African life in different contexts, that is, church, parties, political events and others.

Singing has always been part of worship in a Pentecostal spiritual service. The argument in this article is that Pentecostals take part in singing not only as part of their liturgy but as a way of trying to access therapy for their ailments. The lead singer picks up songs that heal the emotions of the adherents. When such songs are sung, you will hear a Pentecostal say kosha eo e nthoba matswalo, which can be interpreted as 'the song is therapeutic to one's emotions'. In fact, most Pentecostals confess when singing that they are not actually singing but praying. My father used to say Ga se kosha ke thapelo, which literally means that 'it is not a song but prayer'. Consequently, that kind of prayer will bring therapy to their souls.

This article seeks to build on the examples highlighted and establish the theology of singing by looking at scriptures in the Old and New Testaments that speak about singing. The concept of Pentecostal worship will be outlined and explained in detail by looking at literature that deals with Pentecostal worship, especially in an African context. The article will also demonstrate the role played by singing in Pentecostal worship. The purpose is to demonstrate that singing is not only part of liturgy in a Pentecostal spiritual service but acts as a therapeutic agent for all sorts of 
ailments, including emotional, spiritual, psychological and possibly physical ailments.

\section{Singing as a biblical concept}

Singing in the Bible was done to express one's happiness and joy. The women in Israel could sing and dance to show their happiness in welcoming the King. They could play different instruments to demonstrate their joy (1 Sm 18:6). The King himself even in his old age could desire to hear songs sung by human voices (2 Sm 19:35). Especially when done from the heart, singing had an ability to release the presence and glory of God (Is 35:2). The prophet Isaiah uses mountains and the hills as metaphors for singing, on the one hand, and trees of the field as metaphors for clapping, on the other. According to Isaiah, as nature in the form of mountains and hills sings, there shall be joy and peace among the people of God (Is 55:12). This kind of singing has benefits; it brings assurance that God is present, the people of God are safe and well, God is pleased with his people, God will embrace humanity with charity and show humanity kindness (Zph 3:17).

Singing in the Bible was also done to express one's lamentation. The people of Israel had a propensity for lamenting their prophets and the way to do it was through music. An example of this is how women in the book of the prophet Jeremiah lamented for Josiah (2 Chr 35:25). The prophet Isaiah encouraged women who could not give birth to children to sing and to lament in dealing with their dilemmas. The barren women were encouraged to sing because the forsaken woman now has more children than the woman who lives with her husband (Is 54:1). Singing helped the people of God to move from lamentation to joy. The sorrows of those who are troubled are changed into joy.

Singing in the Bible was part of the liturgy in temple worship. The children of Israel ministered with different musical instruments in the tabernacle until Solomon completed the church structure in Jerusalem (1 Chr 6:32). This music incorporated different kinds of instruments and Israelites played the music by all their power, skill and talent (1 Chr 13:8). The priests and the Levites, whom King David chose to be overseers, could also join in singing praises and rejoicing unto the Lord. They also offered different kinds of offerings in the house of God (2 Chr 23:18). Whenever the people of God gathered in the temple to worship God, singing was part of that gathering and helped them to express their emotions to God.

Singing in the Bible was part of thanksgiving. The children of Israel could sing and celebrate to demonstrate what the Lord had done for them over the years. They did so to show sinners that God is able to do great things (Ps 126:2). The prophet Isaiah again uses the heavens, earth, forest and trees as metaphors for singing to celebrate the goodness of the Lord. For God has delivered and has magnified himself among his people. God has comforted his people and will have mercy upon the afflicted (Is 44:23; cf. Is 49:13). During the dedications of the temple, the priests and the Levites could lead the people of God in celebrating with singing and thanksgiving. They could organise different sounds and music to appreciate what God has done in Jerusalem (Neh 12:27). In the New Testament, Paul encouraged the Ephesians and Colossians to speak to themselves in 'Psalms and hymns and spiritual songs, singing and making melody in their heart to the Lord. Giving thanks always for all things unto God and the father in the name of our Lord Jesus Christ' (Eph 5:19-20; cf. Col 3:16).

Lastly, singing in the Bible was part of therapy. The scripture records in 1 Samuel 16 that:

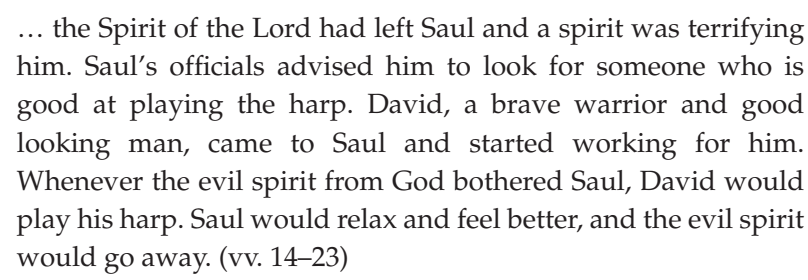

The prophet in Isaiah 51:11 says that the redeemed of the Lord shall return, and come with singing unto Zion; and everlasting joy shall be upon their head: they shall obtain gladness and joy; and sorrow and mourning shall flee away'.

In summary, singing in the Bible was done to express one's joy to the Lord and even unto the people. Equally so, singing was done to express one's lamentation. People were encouraged not to keep silent just because they were in pain but to sing loud in their sorrow. However, their lives would not remain sorrowful but change from sorrow to the joy of the Lord. Singing was also done in temple worship, especially in expressing how people were thankful for what God had done in their lives. The important point in this article that is drawn from the Bible is that singing is part of therapy. People were healed and delivered as others played or sang for them. The link between therapy and singing shall be explained in detail later in the article.

\section{Pentecostal worship}

Pentecostal worship is Spirit worship. It must be stated as a point of departure that Pentecostals believe in baptism in the Holy Spirit (Kgatle 2016:168; cf. Kgatle 2017a:2, 2017b:2). Moreover, Pentecostals embrace the works of the Holy Spirit (Kgatle 2018:1). It is for this reason that 'Spirit worship play [sic] an important role in the spiritual well-being of Pentecostals' (Tshabalala \& Patel 2010:73). This in my view is because Pentecostals are people of the Holy Spirit. They worship according to the Holy Spirit. Thus, Spirit worship is a kind of worship that has moved from the outer to the inner (see Kgatle 2012:33). It is no longer about worshipping in the temple or the mountain, but the hour has come where according to John 4:23-24 'the true worshippers shall worship the Father in spirit and in truth: for the Father seeks such to worship him. For God is a Spirit and they that worship him must worship him in spirit and in truth'. An element of Spirit worship is defined by Manring (2006) as:

... an activity of worship that is distinct from other activities of worship. Ordinarily, these activities of worship are listed in a 
church bulletin (singing, preaching, etc.). Other activities of worship are as follows: prayer, reading, preaching, singing, receiving sacraments, taking vows, fasting, and observing days of thanksgiving. These are all part of liturgy but in Pentecostal worship it is more than liturgy but the Spirit worship. (p. 7)

Pentecostal worship in a way is non-liturgical or has an open liturgy. Vondey (2012) opines that:

In the context of Pentecostalism, the term comprises both a form of spirituality and a form of worship concentrated in the encounter with God. The emphasis of the term is on the free response to this encounter with God rather than on an order or a structure provided for the possibility of that encounter. The only path to integrate Pentecostalism in the existing and often highly structured liturgical landscape is through a rather loose attachment of the term 'liturgy' to the practices of spirituality and worship. In other words, although there might be some form of liturgy in a Pentecostal service, the service itself is not led by such liturgy but led by the Spirit of God. Liturgy comes in as a way of bringing order in the church. While worship as embodied spirituality can be ritualized, the process of formalization and structuring is slow. In this sense, the term liturgy always remains closer to spirituality and worship and resists formal structure, whether imposed by church or culture. The making of a Pentecostal 'liturgy,' therefore, refers more broadly to the actualization of a reflection on the Christian life than to the ordered performance of spirituality in worship. (pp. 149-150)

I want to agree with Vondey, especially on the issue of open liturgy. In my view, it is more correct to speak of an open liturgy among Pentecostals than a 'non-liturgy'. The key point is that a formal programme does not run the service but the Holy Spirit does. Vaughan (2015) puts it this way:

... for the Pentecostals, the true worship leader is the Holy Spirit: Holy Spirit-led worship will always be fresh and invigorating because the Spirit of the Lord is constantly redefining and reexpressing the praises offered to the dynamic and living God. This is the ethos of the Pentecostal message. (p. 240)

A result of the Pentecostal emphasis on spiritual or charismatic experiences is that for Pentecostal people, Spirit worship is the highest occupation of the church, fulfilling the ultimate purpose for which the people of God are redeemed (Is 43:21; 1 Pt 2:9). At the heart of Pentecostalism, Nel (2016) states:

... is its spirituality, and its spirituality was found in worship, one of its major expressions. The phenomenal growth of Pentecostalism has also been ascribed to the attractiveness of its worship. Pentecostalism's greatest and most important contribution to the larger Christian tradition has been in the sphere of liturgy (including music) and preaching, that is, the practice of Spirit worship. (p. 1)

In Spirit worship, according to Akpanika (2012:408), the gospel band leads the congregation in such emotional songs to 'usher in' the presence of the Holy Spirit and to prepare people for the sermons. It is common to see people crying, falling and displaying strange feelings and pneumatic phenomena during worship services. In this kind of worship, as described by Akpanika, at times preachers are unable to deliver a sermon not because they are unprepared to do so but because the Spirit of God has taken over the service. I have had many experiences in my own life as a preacher whereby I had to either stop preaching or not preach at all not because I was too lazy to do so but because God had filled the temple with his power. It is sometimes difficult to express this feeling in words. Spirit worship in a way opens up the platform for people to receive therapy for different aliments. This is because of one reason: it is not the preacher that heals people but the Spirit of God and the blood of Jesus.

Pentecostal worship is alive with different kinds of music. Pentecostals, according to Williams (2016:45), 'focus their worship on music and therefore a significant part of their service revolves around the music and singing'. I will argue that music is part of preparation but not necessarily the focus of the Pentecostal worship service. The focus, I reiterate, is the Holy Spirit because the Holy Spirit leads even the band that leads the music. However, music can serve as motivation, especially to young people, who may perceive the service as boring without live music. Although Pentecostal worship has danceable music, hymns and choruses from various mainline churches, the Holy Spirit is in charge of that music (see Chitando 2002:66). However, Pentecostal music is an important part in the process of evangelisation and its effects cannot be limited to one group of people or one locality. It goes beyond the individual religious communities, regardless of the fact that people could be members of different denominations, and creates the boundaries of the group of believers through the spread of spiritual songs via the Internet and media (Slavkova 2012:2).

Pentecostal worship is participatory. Pentecostal worship praxis claims, according to Williams (2016:46), a set of participatory 'manners' that centre on distinctly somatic ecstatic performances of effusive singing, dancing, therapy and speaking in tongues. In addition, Murango (2015) says:

Pentecostal worship is characterised by joyful singing and dancing, clapping of hands, physical expressions of praise accompanied by loud and powerful instrumentation. Thus, Pentecostal worship is viewed as exuberant and exciting, with a strong emphasis on singing, dancing and the use of popular styles of the day. (p. 1)

Udok and Odunuga (2016) state:

While Pentecostal congregations do sing and worship corporately, individual worshippers can also show an expression of their love and devotion to God as their hearts and spirit of God move them. It is common for Pentecostal churches to include a full musical orchestra or band that musically motivate the entire congregation to worship God with their emotions. (p. 56)

Pentecostal worship has an emotional feeling. Pentecostal worship of both hymn and chorus singing, according to Lebaka (2014:3), added, '[t]he emotional, communal 
feeling needed to help build the Christian community'. Pentecostalism fulfilled the emotional needs of the converts by showing them a path for salvation through faith and giving them an opportunity to praise and bless God by singing and dancing in the spirit. It also aimed at creating new opportunities for self-organisation of the communities and building a community life conforming to a new moral order (Slavkova 2012:2). In conclusion, on this matter, Pentecostal worship is able to play different music, is participatory and is guided by emotion because it is Spirit worship.

\section{The role of singing in Pentecostal worship}

According to Vaughan (2015), Pentecostals:

... brought old songs from other mainline churches with them to church and instead of performers singing to an audience, they began actively participating in the singing as a congregation. Early Pentecostals loved congregational singing, becoming a mainstay of their worship. (p. 4)

In recent times Pentecostals not only sing songs from other denominations or mainline churches but also create or write new songs based on the Bible. African Pentecostals write more songs in their languages in order for people to flow in their own indigenous languages. This view is supported by Atpanika (2012), who says:

... today the Africans sing Gospel Songs with meaning and the lyrics are in vernacular, so they understand the song well. They also express their feelings in a meaningful manner. Local rhythms have been woven into local choruses in most of the African Christian communities and the rhythms naturally evoke local dances and choreographies. (p. 406)

Moreover, African Pentecostals need to translate the existing English songs into indigenous languages in the context of decolonisation and Africanisation. This should be done for the reason that as much as Pentecostals sing in the Spirit they should also sing with understanding. However, it must be acknowledged that in many churches today they display the lyrics of the song on a projector so that the congregants can easily flow with the lead singer.

Participatory, spontaneous and active worship normally involves the entire congregation led by a chorus leader and backed up by a team of instrumentalists. In other words, it is not only the role of the choir or what some churches refer to as the 'worship team'; the whole congregation must take part in the singing rather than only relying on the lead singer. The lead singer must equally be in tune with the musical instruments and musical arrangement of the day. The practice of singing, according to Manring (2006:14), includes 'the words that are sung and the musical arrangement that is selected'. In addition, Nel (2016:4) says, 'Pentecostal singing is experiential and dynamic, with the worshiper and worshiping community being responsive to the Spirit's movement into the glory of God, realised already in part but not yet in fullness'.
Popular music styles performed in churches today may not have originated from the sacred world, although they are powerful tools in the evangelisation process. Gestures such as clapping, raising hands and dancing were widespread. The use of musical instruments during worship as well as singing of choruses with a mixture of music styles was a common feature (Murango 2015:61). These Pentecostal churches are known for a unique style of singing choruses known as praise and worship. This is often done spontaneously with handclapping, singing, shouting, dancing, speaking in tongues and prophesying. Praise and worship, being one of the exuberant characteristic activities of Pentecostal churches, has from the inception of the Pentecostal Church realised its performance as a spiritual electric current with an emotional switch that can ignite power (Udok \& Odunuga 2016:56).

It is during the singing in Pentecostal worship, according to Modiko (2011), that:

... people receive their healings even before they are touched or
prayed for. The general view is that the singers and dancers
releases [sic] more power in casting out evil spirits. The spirits in
a plagued person are lured into putting in an appearance by
means of song and dancing and in accompaniment to the rhythm
of the hypnotic background singing the demon is exorcised
through the laying-on of hand and by prayer. (p. 46)

Wouters (2014:149) concurs that 'performing sacred church songs is, in effect, praying and it calls down the Holy Spirit. The Holy Spirit then plays the role of healing the sick person'. According to Pewa (1997:87), the basic idea is that singing is used as a tool for communication between the congregants and God. Singing is used as a medium of dwelling and spending time in the presence of the Holy Spirit, who then performs therapy upon the sick individuals. This is what makes singing an integral part of Pentecostal worship. In addition, singing unites people and soothes their innermost feelings.

The ultimate expression is the personal song of a person who needs healing; that person moves from a passive state (receiving songs from others) to an active and powerful one, during which they compose and sing a song that instructs others in the community. At the end the sick person receives healing even before the ministers pray for them. When the minister finally gets an opportunity to pray, it is in the form of confirmation and affirmation that indeed the sick person has already been healed and delivered (Van den Bosch-Heij 2013:41). Thus, singing in Pentecostal worship plays the role of prayer more than the role of music or even liturgical exercise. As I said in the introduction, singing is a form of prayer made to God by Pentecostals. As in the Bible, singing helps the people to receive their healing, as in the case of Saul, whose evil spirit was exorcised as David played a harp. Therefore, singing precedes the exorcism of demons and the healing of a sick person. I am now going to demonstrate how singing has 
the ability to heal spiritual, physical, emotional and psychological ailments.

\section{Singing as therapeutic agent}

Singing in Pentecostal worship offers spiritual therapy. It has already been established that Pentecostal worship is Spirit worship. It connects to the spiritual well-being of the members. Thus it becomes a spiritual therapy in the lives of the congregants. The main question is, how is this done? To answer this question, Kidwell (2014) says:

Spirituality is becoming more integrated into approaches of healthcare providers. Specifically, for patients with a terminal diagnosis, addressing the whole person becomes essential in providing comprehensive care, recognizing not only the need to manage physical symptoms for comfort, but determining and treating spiritual needs with regards to impending death. (p. 129)

In other words, not all people are physically sick; some are spiritually sick, and dealing with a holistic person as suggested by Kidwell is beneficial. Thus, singing becomes an important part of Pentecostal worship, especially as it serves as spiritual therapy (Chitando 2002:66). Nel (2016) adds:

Through the agency of the Spirit, the singing becomes a means of grace, and in many instances of therapy. As in preaching, the presence and working of the Spirit is the constituting factor changing a ritual into a life-transforming event and serving to instruct, exhort and model the life of faith. (p. 5)

In addition, according to Wlodarczyk (2003), singing can be:

... a catalyst for spiritual exploration. Singing can structure life review for the patient through which spiritual distress may be alleviated if there are issues of the past that need to be dealt with. Singing can help patients' reminiscence about spiritual events throughout their life, such as births, deaths, weddings and funerals. The time of death vigil is another setting in which creating atmosphere or sacred space through singing can be very comforting. (p. 1)

Pentecostals like singing during a night vigil as a way of giving spiritual support to the members of a bereaved family. They sing the whole night to make sure that the family is comforted throughout their time of grief. The family is encouraged to attend the night vigil so that they can sing along. Thus singing is able to address the spiritual part of a person that normal therapeutic means cannot address; in the end the sick person is able to receive their healing. In some instances, spiritual healing is able to translate into physical, emotional or psychological healing. This brings us to our next point of discussion.

Singing in Pentecostal worship offers physical therapy. Singing in the church, especially the singing of spiritual songs, can also include songs of testimony of physical diseases. Singing, in the words of Vaughan (2015:68), 'is one of the duties of Christians, including praying and testifying, claiming practice of these duties keeps one healthy'. Singing has the potential to heal physical ailments in a Pentecostal service; the more people sing, the more they attract the power of God to heal any physical ailment. It might not be a direct link to such healing but there is a connection between the healing of different diseases and the power of singing. One is not able to quantify at this stage but there are incidences even in the Bible that show that people were healed of their physical diseases through singing. It might be important in the future to do an empirical study on physical therapy through singing.

Singing in Pentecostal worship offers emotional therapy. Everybody who likes to sing, according to Lazar (2005):

... knows that singing is the source of a strong positive experience. Positive experiences are very important in life; they provide the power and motivation to do something less pleasant. Such positive experiences are common activities: playing, singing, and dancing. (p. 195)

However, in Pentecostal worship, singing is more than a positive experience; as already highlighted, it is a spiritual activity that is able to deal with emotional problems. Tshabalala and Patel (2010:76) concur that in Pentecostal worship singing plays 'a key role in the experience of "renewal" and "connection". Emotional health benefits may be linked with specific types of worship in which there is singing, shouting, and movements that encourage an emotional release'. This is because, according to Freinkel (2015):

... a person's inner state is mirrored in the voice by the way they use the vocal tract. Singing may heal and integrate these wounds. Singing creates an inner beat, an inner beat and resonate with it. The deeper and more attentively we are able to listen the deeper we are able tap into the flow of life. (p. 14)

Calitz (2017:8) adds that, in Pentecostal worship, 'songs of praise, lament, worship, benediction, reframing, participation and others facilitate therapy for all the emotions of grief, anger, aggression, depression, disappointment, etc. the congregational singing intended to ask, understand, reframe, encourage and so forth'.

Singing has a profound impact on the well-being of adherents. It largely makes people happy to use their gifts to improve on the happiness of others and ultimately their own happiness. Singing in a church setting offers church members an opportunity to express themselves in the presence of God, which in a way brings them happiness (Joseph \& Petersen 2015:63). The emotional effect of singing, according to Gretsch (2013):

... mainly operates through social resonance and the sense of communion with the group. The participants react to the singing and its associated lyrics by opening themselves up to contact with one another. In addition, active singing, in tandem with dance movements, promotes self- in the encounter with other group members. (p. 249)

As discussed, Pentecostal worship is very much participatory and done in the form of a group. Pentecostal worship possesses abilities to heal people emotionally. 
Singing and dancing in Pentecostal worship offer psychological therapy. The power of singing, according to Van de Laar (2000):
... was also recognised as a psychological therapy tool. The most famous example of this is David's playing of the (harp) to soothe Saul: And so it was, whenever the spirit from God was upon Saul, that David would take a harp and play it with his hand. Then Saul would become refreshed and well, and the distressing spirit would depart from him. While this is a case of psychological 'therapy' administered through music, the Hebrews believed firmly that even physical ailments could be healed with the aid of music. (p. 48)

In Pentecostal worship, as the lead singer takes a song, the congregants are able to forget about their troubles and enjoy the presence of God. The challenge is that sometimes this kind of therapy is not sustainable in my view. The reason is that after the Pentecostal worship, when a person is in a normal state of mind, he or she is able to again recall the trouble that he or she is going through. Thus for sustainable psychological therapy in Pentecostal worship, there is a need for counselling in addition to what the person has received during the service. Moreover, it is important to state categorically that God is the one who heals (not the music) and he chooses how he wants to heal and who he wants to heal. He works in mysterious ways, and we as human beings cannot force or manipulate him to work. Singing becomes a spiritual discipline that positions believers before God in order for God to heal them. In addition, singing is not the only therapeutic agent in Pentecostal worship; other spiritual disciplines like prayer do play a part.

\section{Conclusion}

Singing has always been part of a spiritual service in Pentecostal worship. This article established the theology of singing by looking at scriptures in the Old and New Testaments that speak about singing. The article found that singing in the Bible was done to express one's happiness and joy. Singing in the Bible was also done to express one's lamentation. Singing in the Bible was part of liturgy in temple worship and thanksgiving. More than ritualistic, religiosity and liturgical functions, singing in the Bible was part of therapy. The article also found that Pentecostal worship is more than liturgical worship; it is about Spirit worship by using different kinds of instruments. This is based on the fact that Pentecostals embrace the works of the Holy Spirit. Pentecostal worship is a participatory worship that eases one's emotional tensions. The article also demonstrated the role played by singing in Pentecostal worship. Given the role that singing plays in Pentecostal worship, it has been proven here that singing has potential to heal especially spiritual, psychological and emotional sickness. Further studies are needed, especially empirical studies with evidence that will look at the role of singing as a therapeutic agent for physical ailments. Such a study would be able to quantify the number of people healed.

\section{Acknowledgements}

The author acknowledges the support from the Department of Christian Spirituality, Church History and Missiology, University of South Africa.

\section{Competing interests}

The author declares that he does not have any competing interests with regard to the writing of this article.

\section{Funding information}

Funding for this study was provided by the University of South Africa.

\section{References}

Akpanika, E.N., 2012, 'Christianity in Africa: The renewal of indigenous music: A case study of the Presbyterian church of Nigeria', American Journal of Social Issues \& Humanities 2(6), 406-411.

Calitz, C.J., 2017, 'Healing liturgy: The role of music and singing', Verbum et Ecclessia 38(1), 1-9.

Chitando, E., 2002, Singing culture: A study of gospel music in Zimbabwe, Nordic Africa Institute, Uppsala, Sweden.

Freinkel, P.D., 2015, 'Singing and participatory spirituality', International Journal of Transpersonal Studies 34(1), 1-16.

Gretsch, R., 2013, 'Musical life stories: Narratives on health musicking', Centre for Music and Health Publications Series 6(1), 241-262.

Joseph, D. \& Petersen, A., 2015, 'Music in worship: Making spiritual connections through sound', Vir die Musiekleier 35, 56-67.

Kgatle, M.S., 2012, The five weapons of prayer, Lulu Press, Morrisville, North Carolina.

Kgatle, M.S., 2016, 'Servant leadership in Mark 10:35-45 applied to African Pentecostal Christianity', Doctoral dissertation, University of Pretoria.

Kgatle, M.S., 2017a, 'The unusual practices within some neo-Pentecostal churches in South Africa: Reflections and recommendations', HTS Teologiese Studies/ Theological Studies 73(3), a4656. https://doi.org/10.4102/hts.v73i3.4656

Kgatle, M.S., 2017b, 'African Pentecostalism: The Christianity of Elias Letwaba from early years until his death in 1959', Scriptura 116(1), 1-9.

Kgatle, M.S., 2018, 'Integrating African Pentecostalism into the theological education of South African universities: An urgent task', HTS Teologiese Studies/Theological Studies 74(3), 5130. https://doi.org/10.4102/hts.v74i3.5130

Kidwell, M.D., 2014, 'Music therapy and spirituality: How can I keep from singing?', Music Therapy Perspective 32(2), 129-135.

Lazar, K., 2005, 'Why play and sing? The role of folk games and folk songs in everyday life', Traditiones 34(1), 191-197.

Lebaka, M.E.K., 2014, 'Music, singing and dancing in relation to the use of the harp and the ram's horn or shofar in the Bible: What do we know about this?', HTS Teologiese Studies/Theological Studies 70(3), art. \#2664, 7 pages. https://doi. Teologiese Studies/Theological
org/10.4102/hts.v70i3.2664

Manring, N.D., 2006, 'The element of dance in worship', Master's thesis, Reformed Theological Seminary.

Modiko, B.V., 2011, 'The concept of healing power in the African Initiated Churches (AICs) with special reference to the Vaal Triangle', PhD dissertation, North-West University.

Murango, A.K., 2015, 'The influence of popular music styles on music training in Pentecostal churches of Kenya: The case of house of grace church ministries in Nairobi', Master's research project, Kenyatta University, Kenya.

Nel, M., 2016, 'Attempting to develop a Pentecostal theology of worship', Verbum et Ecclesia 37(1), a1661. https://doi.org/10.4102/ve.v37i1.1661

Pewa, S.E., 1997, 'Song, dance and worship in the Zionist Christian Churches: An ethnomusicological study of African music and religion', Master's dissertation, University of Zululand Kwa Dlangezwa.

Slavkova, M., 2012, 'Singing and dancing in the spirit. Gypsy Pentecostal music and musicians', Journal of the Slovakian Association for the Study of Religions 2(1), 36-46.

Tshabalala, B.G. \& Patel, C., 2010, 'The role of praise and worship activities in spiritual well-being: Perceptions of a Pentecostal youth ministry group' International Journal of Children's Spirituality 15(1), 73-82, https://doi. org/10.1080/13644361003603074

Udok, E.K. \& Odunuga, A.F., 2016, 'Music and Pentecostalism: The Nigerian experience', American Research Institute for Policy Development 5(1), 52-60. 
Van de Laar, J.W., 2000, 'A theological exploration of the role and use of music for worship in the Methodist Church of Southern Africa', Master's thesis, University of South Africa.

Van den Bosch-Heij, D., 2013, Spirit and healing in Africa: A reformed pneumatological perspective, African Sun Media, Stellenbosch.

Vaughan, S.B., 2015, 'The influence of music on the development of the church of God', PhD dissertation, University of Birmingham, United Kingdom.

Vondey, W., 2012, 'The making of a Black liturgy: Pentecostal worship and spirituality from African slave narratives to American cityscapes', Black Theology 10(2), 147-168.
Williams, A., 2016, 'Spiritual landscapes of Pentecostal worship, belief, and embodiment in a therapeutic community: New critical perspectives', Emotion, Space and Society $19,45-55$.

Wlodarczyk, N., 2003, 'The effect of music therapy on the spirituality of persons in an in patient hospice unit as measured by self-report', Master's thesis, University of in patient hospic

Wouters, J.M.F., 2014, 'An anthropological study of healing practices in African Initiated Churches with specific reference to a Zionist Christian Church in Marabastad', PhD dissertation, University of South Africa. 